ISSN 0258-7122 (Print), 2408-8293 (Online)

Bangladesh J. Agril. Res. 43(2): 175-186, June 2018

\title{
CHARACTERIZATION, IDENTIFICATION AND ANTIBIOGRAM STUDIES OF ENDOPHYTIC BACTERIA FROM COWPEA [Vigna unguiculata (L.) Walp]
}

\author{
L. W. MARZAN ${ }^{1}$, R. AlAM ${ }^{2}$ AND M. A. HossAIN ${ }^{3}$
}

\begin{abstract}
This study included isolation, characterization and identification of endophytic bacteria from cowpea [Vigna unguiculata (L.) Walp] roots from Hathazari upazilla, Chittagong, Bangladesh and three specis of bacteria, Staphylococcus intermedius, Staphylococcus caprae and Staphylococcus saprophyticus were finally identified based on their morphological and biochemical characteristics according to established protocol. Results of antibiotic sensitivity pattern of those endophytic bacteria suggested that they can be utilized as a cost-effective biological control agent in future applications, such as delivery of enzymes for controlling certain plant diseases against various pathogens. The findings of this study may help to determine the potential application of those endophytic bacteria in biotechnology, medicine and agriculture.
\end{abstract}

Keywords: Endophytic bacteria, biochemical identification, Staphylococcus intermedius, Staphylococcus caprae, Staphylococcus saprophyticus, biocontrol agent.

\section{Introduction}

Bacteria defined as 'endophyte' are those that live within a plant for at least a part of their life without causing any apparent harm (Anderson et al., 2008) and could also establish a mutualistic association (Azevedo et al., 2000) to their host. Plants constitute vast and diverse niches for these endophytic organisms. It is worth mentioning that each plant species is a host to a number of bacteria which are living inside plant tissues, form associations ranging from pathogenic to symbiotic. Beneficial relationships include symbiosis; endophytes supply the plants with fixed nitrogen and other endophytic associations that promote plant growth by producing phytohormones, volatiles, defense compounds and enzymes (Hooper, 2001; De Matos et al., 2001). Endophytes are sheltered from environmental stresses and microbial competition by the host plant and they seem to be ubiquitous in plant tissues, having been isolated from flowers, fruits, leaves, stems, roots, rhizomes and seeds of various plant species (Sturz et al., 2000). Some endophytic bacteria exert several beneficial effects on host plants, such as stimulation of plant growth (Kobayashi and Palumbo, 2000), nitrogen fixation (Sturz et al., 1997) and induction of resistance to plant pathogens (Liu,

${ }^{1 \& 2}$ Department of Genetic Engineering and Biotechnology, Faculty of Biological Sciences, University of Chittagong, Chittagong- 4331, ${ }^{3}$ Department of Genetic Engineering and Biotechnology, Jagannath University, Dhaka 1100, Bangladesh. 
1995; Sturz and Matheson, 1996). The potential for practical applications of endophytes has led to studies addressing the bacteria's ability to control both disease and insect infestations, as well as promoting plant growth (Kavino et al., 2007).

Cowpea is major legumes, grown in Bangladesh which contributes a prominent portion of total pulse production of Bangladesh, providing an average yield of $871 \mathrm{~kg} / \mathrm{ha}$ and net return to $11,805 \mathrm{BDT} / \mathrm{ha}$ (Salam and Kamruzzaman, 2016). It is an annual herb having a strong principal root and many spreading lateral roots in surface soil (Sheahan, 2012). They are rich in potassium, calcium, magnesium, phosphorus and also small amount of iron, sodium, zinc, copper, manganese, selenium, vitamin $\mathrm{A}, \mathrm{B}_{6}$ and $\mathrm{C}$, as well as thiamin, riboflavin, niacin and pantothenic acid.

Cowpea suffers from its natural enemies. Various types of insects are the worst of these enemies, but nematodes, bacterial diseases and viruses also cause losses. Reliable published data are available which show evidence that insects cause devastating losses in cowpea yields. Aphids - pre harvest pest can affect cowpea at the growing season. Weevils - post harvest pest, can destroy a granary full of cowpeas within two or three months. But people need to have the grain to eat for 12 months in a year (Sheahan, 2012).

A large number of bacterial and fungal pathogens have been reported to infect crop plants which ultimately decrease their yield and hence reduce profit (Heath, 1998). Chemical treatment to prevent such incidence seems to be an easy solution but with an effect to the healthy environment and even our lives. Soil degradation and groundwater pollution are the ultimate results of over dependence on pesticides. Moreover, pesticide residues also sometimes raise food safety concerns (Gupta and Dikshit, 2010). Considering these adverse outcomes, biological controls to plant pathogens are getting immense importance day by day. Based on microorganisms, biopesticides specific to a target pest offer an ecologically sound and effective solution to pest problems. They pose less threat to eco-friendly approach to pest control (Gupta and Dikshit, 2010). Several endophytic bacteria were found to exert antimicrobial as well as antifungal effects on a number of crops (Oryza sativa, Glycine max), that contain several enzymes which will act as an inhibitor of their pest's digestive system and can be effective for pest control (Sunkar and Nachiyar, 2013).

Therefore, the aim of this study is to detect and isolate the eco-friendly endophytic bacteria from the roots of Vigna unguiculata, (L.) Walp to study their morphological and biochemical characteristics to identify those bacteria up to species level; and finally antibiotic susceptibility were tested in order to use them as a biocontrol agent (spray) (Nandakumar et al., 2001, Damodaran et al., 2017) in bioremediation scheme. 


\section{Materials and Methods}

\section{Sampling area and collection of samples}

Twenty (20) root samples from cowpea [Vigna unguiculata (L.) Walp] plants were collected from various agricultural fields of Hathazari Upazila, Chittagong, Bangladesh (Figure 1). Collected root samples were sealed in sterile zipper bags and labeled. All samples were brought to the Molecular Biology Laboratory of the Department of Genetic Engineering and Biotechnology, University of Chittagong, Bangladesh, by maintaining cold chain and stored them in the refrigerator $\left(4^{\circ} \mathrm{C}\right)$ for further analysis.

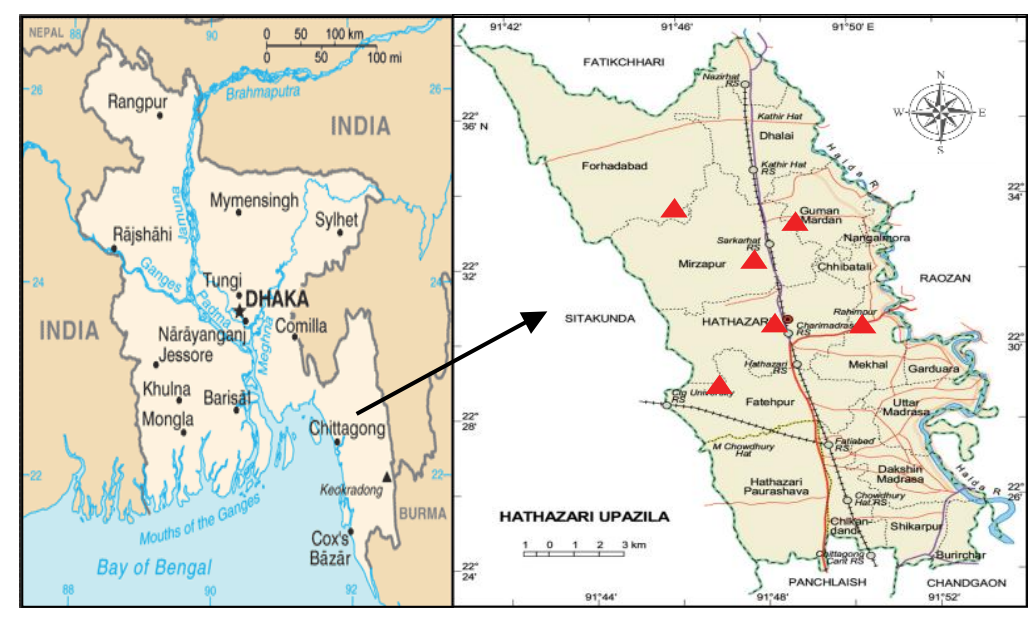

Fig. 1. Sampling sites ( $\triangle$ ) of Hathazari Upazila

\section{Isolation of Endophytic Bacteria from cowpea roots}

The total procedure were done according to Anderson et al. (2008), where samples [healthy fresh roots of Vigna unguiculata (L.) Walp] were collected and cleaned under running tap water to remove debris and then air dried. About 25.0 $\mathrm{gm}$ of 2-3 cm length of roots were cut and surface sterilization was carried out by rinsing them in Tween-20 for 10 minutes, followed by further washing with $\mathrm{dH}_{2} \mathrm{O}$ for at least 7 times. After that, root samples were dipped into $70 \%$ alcohol for 30 seconds, and then the samples were washed with $\mathrm{dH}_{2} \mathrm{O}$. Twenty (20.0) ml of $0.2 \% \mathrm{Hg}_{2} \mathrm{Cl}_{2}$ solution was added to the samples and the beaker was put on a shaker at $240 \mathrm{rpm}$ for 5 minutes at $27^{\circ} \mathrm{C}$. Then the samples were washed again with $\mathrm{dH}_{2} \mathrm{O}$ for at least 7 times. The final root rinsed water, was used as control and spread onto nutrient agar plate (Addisu and Kiros, 2016), which contained $(\mathrm{g} / \mathrm{L})$ - peptone 5.00, beef extract 2.00, yeast extract 3.00, $\mathrm{NaCl} 5.00$ and agar 18.00 , where $\mathrm{pH}$ was adjusted to 7.0. For the isolation of endophytic bacteria, root pieces were further triturated in sterile Phosphate buffer saline (PBS) (Anderson et al., 2008) containing (g/L) - $\mathrm{NaCl} 8.00, \mathrm{KCl} 0.20, \mathrm{Na}_{2} \mathrm{HPO}_{4} 1.44$ and $\mathrm{KH}_{2} \mathrm{PO}_{4} 0.24$, where $\mathrm{pH}$ was adjusted to 7.4 and maintained at $28^{\circ} \mathrm{C}$ under 
$150 \mathrm{rpm}$ agitation. All plates including control were incubated at $37^{\circ} \mathrm{C}$ for 5 days and the number of $\mathrm{CFU}$ was determined to estimate bacterial population density according to Addisu and Kiros (2016).

Following purification, morphologically distinct colonies were identified by observing colony characteristics such as gram nature, color, shape using a binocular biological microscope (XSZ-107BN), where colonies of similar morphological features were grouped into the same species (Castillo et al., 2003; Beiranvand et al., 2017). Then isolates were selected, cultured, purified and stored in the laboratory at $-80^{\circ} \mathrm{C}$ in glycerol stock (50\%) solution for further studies.

\section{Phenotypic and biochemical characterization of endophytic bacterial isolates}

Standard morphological and biochemical tests were performed for the identification of endophytic bacteria. They were characterized by gram staining and biochemical tests as described in the Cowan and Steel's Manual for the identification of Medical Bacteria (Barrow and Feltham, 1993). For the activities of oxidase, catalase, coagulase, citrate and carbohydrate (Maltose, Sucrose, Mannitol, D-Xylose and L-Rhamnose) fermentation, isolates were biochemically analyzed (Barrow and Feltham, 1993). Then according to Bergey's Manual of systemic Bacteriology the isolates were provisionally identified up to species level (Claus and Berkeley, 1986).

\section{Determination of antibiotic sensitivity}

Susceptibility of three (3) finally identified isolates to different antibacterial agents was measured in vitro by employing the modified Kirby-Bauer (Bauer $e t$ al., 1966) method. This method allows for the rapid determination of the efficiency of a drug by measuring the diameter of the zone of inhibition that results from diffusion of the agent into the medium surrounding the disc (Wayne, 2009). Commercially available eight (8) antibiotic discs (Himedia, India) were used for the tests. The antibiotics that were tested against three isolates of this study have been listed in Table 2 .

\section{Statistical analysis}

Triplicate experiments were done in all the cases during isolation, biochemical analysis and antibiotic sensitivity tests of the selected isolates. The results were measured as the mean value \pm standard deviation (SD) in triplicate. Data were captured into Microsoft Excel Software, version 2010 to calculate means and standard deviations.

\section{Results}

\section{Screening and Isolation of endophytic bacteria}

After preliminary screening of the collected samples, surface sterilization was done as described previously (Anderson et al., 2008), then root extraction was 
prepared to isolate distinct bacterial colonies and plated them on NA (Nutrient agar) medium. Then three different morphologies and colored isolates were finally selected for further studies named as W (white), PW (pale-white) and Y (yellow) (Figure 2).

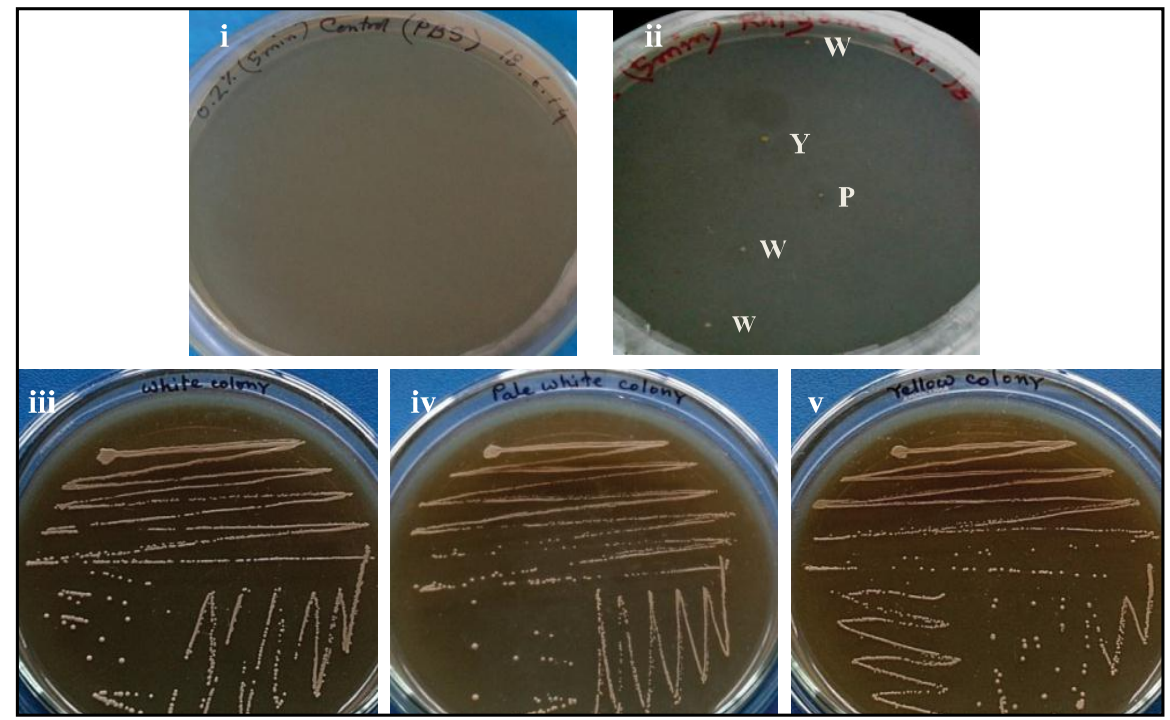

Fig. 2. Control (i) and mixed culture plate (ii); Subculture of bacterial isolate from white, pale white and yellow colony (iii, iv, v).

\section{Characterization and identification}

Three selected potential endophytic isolates (W, PW and Y) were characterized on the basis of their morphological and biochemical characteristics (Table 1). They were compared with standard description of Bergey's Manual of determinative bacteriology 9th edition (Bergey et al., 1974; Bergey and Holt, 1994), the isolates were provisionally identified up to species level and are consistent with past field studies (Claus and Berkeley, 1986).

Table 1. Morphological and Biochemical Characteristics of Endophytic Bacteria

\begin{tabular}{l|c|c|c}
\hline \multicolumn{1}{c|}{ Bacterial isolates } & W & PW & Y \\
\hline $\begin{array}{l}\text { Morphological } \\
\text { characteristics } \\
\text { Colony color }\end{array}$ & & & \\
Gram Nature & White & Pale-white & Yellow \\
Cell Shape & Positive & Positive & Positive \\
Biochemical Test Results & Cocci & Cocci & Cocci \\
Catalase & & & + \\
\hline
\end{tabular}




\begin{tabular}{lccc}
\hline Coagulase & + & - & - \\
Oxidase & - & - & - \\
Citrate & + & + & + \\
$\begin{array}{l}\text { Utilization of Carbohydrates } \\
\text { Maltose }\end{array}$ & + & - & - \\
Sucrose & + & - & + \\
Mannitol & - & - & + \\
$\begin{array}{l}\text { D-Xylose } \\
\text { L-Rhamnose }\end{array}$ & - & - & - \\
$\begin{array}{l}\text { Provisionally } \\
\text { Bacteria }\end{array}$ & Identified & Staphylococcus & Staphylococcus \\
Claus and Berkeley (1986) & intermedius & Staphrae & saprophyticus \\
\hline
\end{tabular}

Note: $(+)$ and (-) indicates positive and negative results respectively

\section{Antibiotic sensitivity test}

All three different isolates were tested for their antibiotic susceptibility against the eight (8) commonly prescribed antibiotics: Ampicillin (AMP), Bacitracin (B), Kanamycin (K), Penicillin G (P), Rifampicin (RIF), Streptomycin (S), Trimethoprim (TR) and Vancomycin (VA) according to the protocol mentioned previously. The antibiotic response was measured by inhibition zone creating by selected endophytes (sample and control), which revealed that all $(n=3)$ were susceptible to 7 (seven) antibiotics (Wayne, 2009; CLSI M100-S21), whereas they $(n=3)$ were resistant to Ampicillin (AMP) and only PW isolate were resistant to Bacitracin (B) (Table 2; Figure 3).

Table 2. Antibiotic Susceptibility Tests

\begin{tabular}{|c|c|c|c|c|c|}
\hline \multirow{3}{*}{ Antimicrobial Agent } & \multirow{3}{*}{ Disc code } & \multirow{3}{*}{$\begin{array}{c}\text { Disc potency } \\
(\mu \mathrm{g})\end{array}$} & \multicolumn{3}{|c|}{ Bacterial isolates } \\
\hline & & & $\mathrm{W}$ & PW & $\mathrm{Y}$ \\
\hline & & & \multicolumn{3}{|c|}{ Zone ranges $(\mathrm{mm})$} \\
\hline Ampicillin & AMP & 10 & $12(\mathrm{R})$ & $17(\mathrm{R})$ & $10(\mathrm{R})$ \\
\hline Bacitracin & B & 10 units & $24(\mathrm{~S})$ & $15(\mathrm{R})$ & $21(\mathrm{~S})$ \\
\hline Kanamycin & $\mathrm{K}$ & $30 \mu \mathrm{g}$ & $29(\mathrm{~S})$ & $28(\mathrm{~S})$ & $35(\mathrm{~S})$ \\
\hline Penicillin $G$ & $\mathrm{P}$ & 10 & $34(\mathrm{~S})$ & $33(S)$ & $28(S)$ \\
\hline Rifampicin & RIF & $5 \mu \mathrm{g}$ & $34(\mathrm{~S})$ & $35(\mathrm{~S})$ & $39(\mathrm{~S})$ \\
\hline Streptomycin & $\mathrm{S}$ & 10 & $21(\mathrm{~S})$ & $25(\mathrm{~S})$ & $25(\mathrm{~S})$ \\
\hline Trimethoprim & TR & 25 & $17(\mathrm{~S})$ & $26(S)$ & $32(\mathrm{~S})$ \\
\hline Vancomycin & VA & 30 & $22(S)$ & $22(\mathrm{~S})$ & $23(\mathrm{~S})$ \\
\hline
\end{tabular}

Note: $\mathrm{R}=$ Resistance, $\mathrm{S}=$ Susceptible 


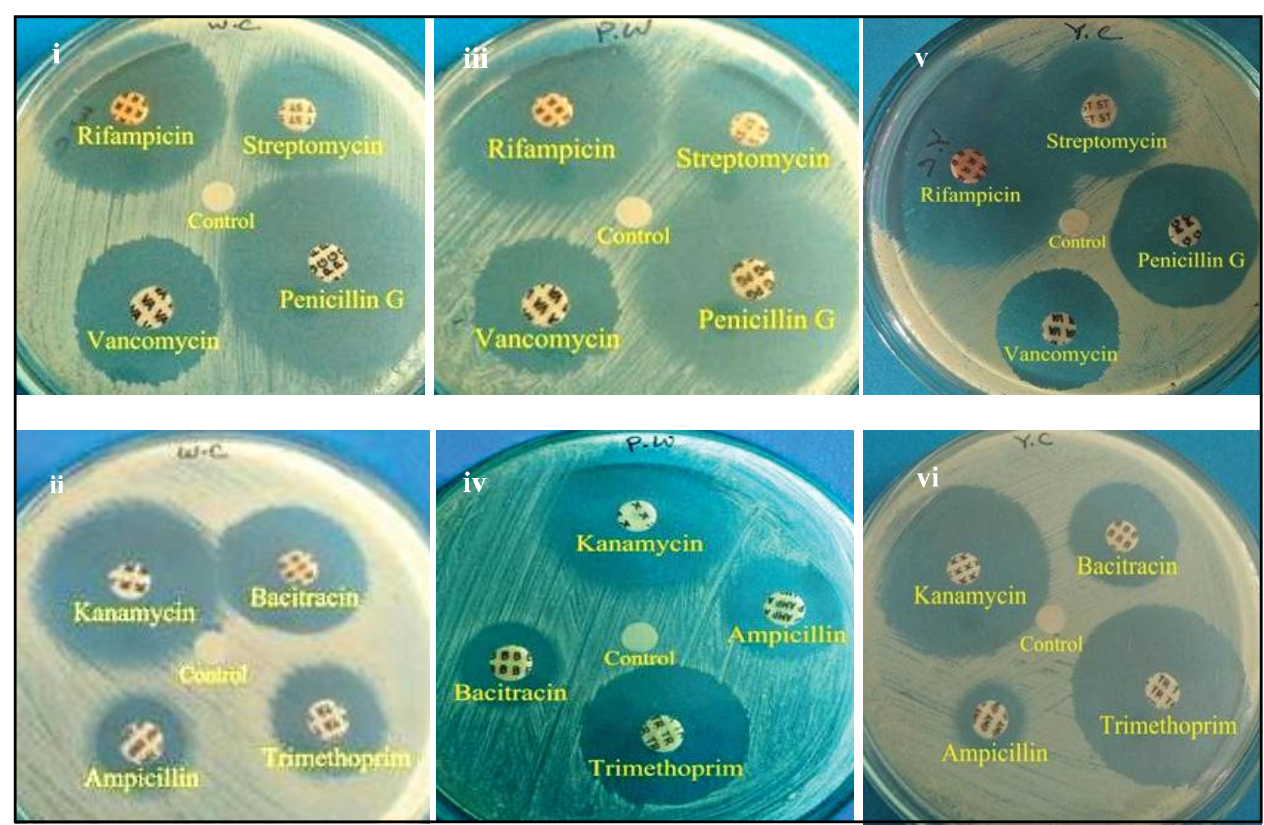

Fig. 3. Antibiotic sensitivity tests; $\mathrm{WC}=\mathrm{i}$ and $\mathrm{ii} ; \mathrm{PW}=\mathrm{ii}$ and $\mathrm{iv} ; \mathrm{YC}=\mathrm{v}$ and vi

\section{Discussion}

Plants harbor a number of endophytic bacteria and fungus species. Of the nearly 300,000 plant species on earth, each is likely to be the host to at least one endophyte (Strobel, 2003); but relatively few of their endophytes have been characterized so far. So, the major focus of this study was to isolate, characterize and identify the endophytic bacteria from healthy cowpea [Vigna unguiculata (L.) Walp] roots which can be used as bio-control agent as an alternative to pesticides that may mitigate environmental pollution as well.

After sample collection, following purification and visual observation of growth, three different types and colors of colonies were selected initially from culture plate as: W (white), PY (pale-white) and Y (yellow) (Figure 2).

The bacterial isolates were then characterized by morphological and biochemical characteristics (Table 1). Identification of bacterial isolates was done according to Bergey's Manual of determinative bacteriology 9th edition (Bergey et al., 1974; Bergey and Holt, 1994; Barrow and Feltham, 1993).

Depending on gram staining, three isolates (W, PW and Y) were identified as gram positive bacteria (Table 1) by detecting peptidoglycan which is present in a thick layer in bacteria (Marzan et al., 2017).

During oxidase test all three isolates showed negative results (Thelwell et al., 1998). Catalase positive results indicate the three bacterial isolates (W, PW and 
Y) may be either Micrococcus or Staphylococcus. Besides, isolates PW and Y were found coagulase negative, where $\mathrm{W}$ was found coagulase positive. Beside this, negative result in mannitol salt fermentation test for W, PW found similarities to Micrococcus spp. or Staphylococcus spp. respectively. To confirm, two isolates were observed for their pigmentation properties on mannitol salt agar media, where lack of yellow pigmentation identified both isolates as Staphylococcus spp. During citrate utilization all three isolates showed positive results.

Five carbohydrate utilization tests (Maltose, Sucrose, Mannitol, D-Xylose and LRhamnose) were done, where PW showed negative result in all cases, which is strongly indicative of Staphylococcus caprae (Tille, 2017). On the other hand, the positive result for maltose and sucrose, as well as negative for the other three carbohydrates found for the isolate W, strongly match with Staphylococcus intermedius. Besides, the isolate $\mathrm{Y}$ showed positive result for sucrose and mannitol, but negative for the other three carbohydrates, strongly match with Staphylococcus saprophyticus (Tille, 2017; Bergey et al., 1974).

It was observed that $\mathrm{W}, \mathrm{PW}$ and $\mathrm{Y}$ colony have a close resemblance with Staphylococcus intermedius, Staphylococcus caprae and Staphylococcus saprophyticus, respectively. Bacterial genus Staphylococcus, were found previously as endophyte in various agronomic crops (Costa et al., 2012; Jasim et al., 2013); Staphylococcus caprae and Staphylococcus saprophyticus were found as endophyte in Phaseolus vulgaris (Tille, 2017). The genera isolated in the present study that have been previously reported as endophytes are Staphylococcus caprae and Staphylococcus saprophyticus, where Staphylococcus intermedius is found to be new in our research.

The multidrug resistance problems in microbes increase the demand for further research on novel metabolites obtained from endophytes (Rathod et al., 2012). Eight (8) antibiotic discs were used to assess antibiotic sensitivity, where those endophytes can be a good candidate (inhibition zone against antibiotic in maximum cases) to act as a biocontrol agents; where there is a suitable chance to apply directly (spray) in the agricultural environment (Damodaran et al., 2017). Here all three isolates were showed antibiotic sensitivity against seven (7), and are harmless to environment for suitable application (Alström and Vuurde, 2001) and their antimicrobial activity could be exploited in biotechnology, medicine and agriculture (Gashgari et al., 2016) to control pathogen attack in cowpea and possibly in other plants. A number of endophytic bacteria were reported to prevent the deleterious effects of certain pathogens by producing antimicrobial compunds or inducing systemic resistance in the host plant (Kandel et al., 2017). Hence, discovery of novel and effective antibiotics are necessary (O'Donnell et al., 2010). Some of the pathogenic microorganisms now a day become resistant to the effective antibiotics (Bisht et al., 2009). Recent data showed that endophytes have a novel source to development of highly effective antibiotics 
(Shukla et al., 2015). Hence, invention of effective bio-controlling techniques by using eco-friendly endophytic bacteria, will open a new platform for further studies to fulfill the future demand of cost effective agro-based bio-control agents for plants (Egamberdieva et al., 2017) as well as agricultural systems.

\section{Conclusion}

Depending on morphological and biochemical characteristics three isolates collected from cowpea were provisionally identified as Staphylococcus intermedius, Staphylococcus caprae and Staphylococcus saprophyticus. All the results presented in this study support the concept that three endophytic bacteria have significant antibiotic sensitivity which might be used to formulate them as biocontrol agent against pest, insect or pathogen in bioremediation scheme for agricultural environment.

\section{Acknowledgement}

This research was done in the 'Molecular Biology Laboratory' of the Department of Genetic Engineering and Biotechnology, University of Chittagong and partially funded by the Planning and Development Office of the University of Chittagong (Ref. 196/ P \& D/7-33(40)/ 2015).

\section{References}

Addisu, D., and L. Kiros. 2016. Isolation and identification of bacteria from fresh fruit juices prepared in cafeteria and restaurants, Axum town. Int. J. Inter. Sci. Inno. and Technnol. 5(2): 5-10.

Alström, S., and J. W. Vuurde. 2001. Endophytic bacteria and biocontrol of plant diseases. Plant Patho. Bact. Pp. 60-67.

Anderson, F., M. C. Quecine, P. T. Lacava, S. Oda, J. L. Azevedo and W. L. Araujo. 2008. Diversity of endophytic bacteria from Eucalyptus species seeds and colonization of seedlings by Pantoea agglomerans. FEMS Microbiol. lett. 287: 8-14.

Azevedo, J. L., W. M. Jr, J. O. Pereira and W. L. Araújo. 2000. Endophytic microorganisms: a review on insect control and recent advances on tropical plants. Electro. J. of Biotech. 3(1).

Barrow, G.I. and R.K.A. Feltham. 1993. Cowan and Steel's mannual for the identification of medical bacteria. Camb. Univ. Press, New York, USA, 46(10): 975.

Bauer, A. W., W. M. Kirby, J. C. Sherris and M. Turck. 1966. Antibiotic susceptibility testing by a standardized single disk method. Ame. J. Clin. Pathol. 45: 493-496.

Beiranvand, M., M. Amin, A. Hashemi-Shaharaki, B. Romani, S. Yaghoubi and P. Sadhegi. 2017. Antimicrobial activity of endophytic bacterial populations isolated from medicinal plants of Iran. Iranian J. Microbiol. 9(1): 11-18.

Bergey, D.H., R.E. Buchanan and N.E. Gibbons. 1974. Bergey's Manual of Determinative Bacteriology, Williams and Wilkins Co., Baltimore. Pp. 1246. 
Bergey, D. H. and J. G. Holt., 1994. Bergey's Manual of Determinative Bacteriology, Williams and Wilkins, Baltimore, 9th edition.

Bisht, R., A. Katiyar, R. Singh and P. Mittal. 2009. Antibiotic resistance- a global issue of concern. Asian J. Pharma. and Clinic. Res. 2:24-39.

Castillo, U., J. K. Harper, G. A. Strobel, J. Sears, K. Alesi and E. Ford. 2003. Kakadumycins novel antibiotics from Streptomyces sp. NRRL 30566, an endophyte of Grevillea pteridifolia. FEMS Microbiol. Lett. 224: 183-190.

Costa, L. E., M. V. Queiroz, A. C. Borges, C. A. Moraes and E. F. Araújo. 2012. Isolation and characterization of endophytic bacteria isolated from the leaves of the common bean (Phaseolus vulgaris). Braz. J. Microbiol. 43(4): 1562-1575.

Claus, D. and R.C.W. Berkeley, 1986. Genus Pseudomonus. In: Sneath, P.H.A., Mair, N.S., Sharp, M.E. (Eds.). In: Bergey's manual of systematic bacteriology, Vol 1. Williams and Wilkins, Baltimore. Pp. 140-219.

Damodaran, T., R. B. Rai, S. K. Jha, R. Kannan, B. K. Pandey, V. Sah, V. K. Mishra and D. K. Sharma. 2017. Rhizosphere and endophytic bacteria for induction of salt tolerance in gladiolus grown in sodic soils. J. Plant Interact. Pp. 1742-9145.

De Matos Nogueira, E., F. Vinagre, H. P. Masuda, C. Vargas, V. L. M. de Pádua, F. R. da Silva, R. V. dos Santos, J. I. Baldani, P. C. Gomes Ferreira and Hemerley. 2001. Expression of sugarcane genes induced by inoculation with Gluconacetobacter diazotrophicus and Herbaspirillum rubrisubalbicans. Genet. Mol. Biol. 24:199-206.

Egamberdieva, D., S. Wirth, U. Behrendt, P. Ahmad and G. Berg. 2017. Antimicrobial activity of medicinal plants correlates with the proportion of antagonistic endophytes. Front. in Microbiol. 8(199): 1-11.

Gashgari, R., Y. Gherbawy, F. Ameen and S. Alsharari. 2016. Molecular characterization and analysis of antimicrobial activity of endophytic-from medicinal plants in Saudi Arabia. Jundishapur J. Microbiol. 9(1): e26157.

Gupta, S. and A.K. Dikshit. 2010. Biopesticides: An ecofriendly approach for pest control. J. Biopesticides. 3(1- Special Issue): 186-188.

Heath, M. C. 1998. Involvement of reactive oxygen species in the response of resistant (hypersensitive) or susceptible cowpeas to the cowpea rust fungus. New Phyto. 138(2): 251-263.

Hooper, L. V. 2001. Molecular analysis of commensal host-microbial relationships in the intestine. Science. 291(5505): 881-884.

Jasim, B., A. A. Joseph, C. J. John, J. Mathew and E. K. Radhakrishnan. 2013. Isolation and characterization of plant growth promoting endophytic bacteria from the rhizome of Zingiber officinale. 3 Biotech. 4(2): 197-204.

Kandel, S. L., A. Firrincieli, P. M. Joubert, P. Okubara, N. D. Leston and K. M. McGeorge. 2017. An in vitro study of bio-control and plant growth promotion potential of Salicaceae endophytes. Front. Microbiol. 8:386.

Kavino, M., S. Harish, N. Kumar, D. Saravanakumar, T. Damodaran, K. Soorianathasundaram, and R. Samiyappan. 2007. Rhizosphere and endophytic bacteria for induction of systemic resistance of banana plantlets against bunchy top virus. Soil Biol. Biochem. 39: 1087-1098. 
Kobayashi, D. Y. and J. D. Palumbo. 2000. Bacterial endophytes and their effects on plants and uses in agriculture. In: Bacon CW, White JF Jr (ed.) Microbial Endophytes. Marcel Dekker, Inc.: New York. Pp 199-233.

Liu, L. 1995. Induction of systemic resistance in cucumber against Fusarium wilt by plant growth-promoting Rhizobacteria. Phytopathology. 85(6): 695.

Marzan, L. W., M. Hossain, S. A. Mina, Y. Akter and A. M. M. A. Chowdhury. 2017. Isolation and biochemical characterization of heavy-metal resistant bacteria from tannery effluent in Chittagong city, Bangladesh: Bioremediation viewpoint. Egyptian J. of Aquatic Res. 43(1): 65-74.

Nandakumar, R., R. Viswanathan, S. Babu, J. Sheela, T. Raguchander, R. Samiyappan. 2001. A new bio-formulation containing plant growth promoting rhizobacterial mixture for the management of sheath blight and enhanced grain yield in rice. Biocontrol. 46: 1-18.

O'Donnell, F., T. J. P. Smyth, V. N. Ramachandran and W. F. Smyth. 2010. A study of antimicrobial activity of selected synthetic and naturally occurring quinolones. Int. J. of Antimicrob. Agent. 35: 30-38.

Rathod, D., M. Dar, A. Gade, R. B. Shrivastava, M. Rai and A. Varma. 2012. Microbiological endophytes: progress and challenges. Springer-Verlag Berlin Heidelberg. Pp 101-121.

Salam, M. and M. Kamruzzaman. 2016. Comparative and competitive advantage of soybean cultivation in Noakhali and Laxmipur District of Bangladesh. J. Bang. Agri. Univ. 13(2): 265.

Sheahan, C.M. 2012. Plant guide for cowpea (Vigna unguiculata). USDA-Natural Resources Conservation Service, Cape May Plant Materials Center, Cape May, NJ. Pp 1-3.

Shukla, S., G. Naik and S. K. Mishra. 2015. Potential antimicrobial activity of bacterial endophytes isolated from Flacourita jangomas (Lour.) raeusch, a less explored medicinal plant. J. Microbiol. Biotechnol. and Food Sci. 473-477.

Strobel, G. A. 2003. Endophytes as sources of bioactive products. Microb. and Infec. 5(6): 535-544.

Sturz, A. V. and B. G. Matheson. 1996. Populations of endophytic bacteria which influence host-resistance to Erwinia-induced bacterial soft rot in potato tubers. Plant and Soil. 184(2): 265-271.

Sturz, A. V., B. R. Christie, B. G. Matheson and J. Nowak. 1997. Biodiversity of endophytic bacteria which colonize red clover nodules, roots, stems and foliage and their influence on host growth. Biol. and Fertility of Soils. 25(1): 13-19.

Sturz, A. V., B. R. Christie and J. Nowak. 2000. Bacterial endophytes: potential role in developing sustainable systems of crop production. Critical Rev. Plant Sci. 19(1): 130 .

Sunkar, S. and C. V. Nachiyar. 2013. Isolation and characterization of an endophytic bacterium from Brassica oleracea with potential enzyme and antibacterial activity. Asian J. Pharma. and Clinic. Res. 6(2):183-187. 
Thelwell, C., N. J. Robinson and J. S. Turner-Cavet. 1998. An SmtB-like repressor from Synechocystis PCC 6803 regulates a zinc exporter. Proc. Nat. Acad. Sci. 95 (18): 10728-10733.

Tille, P. M. 2017. Bailey and Scott's Diagnostic Microbiology, 14th ed. Chapter 13. St. Louis, Missouri: Elsevier.

Wayne, P. 2009. Clinical and Laboratory Standards Institute.Clinical and Laboratory Standards Institute. Performance Standard for Antimicrobial Susceptibility testing;, Nineteenth Informational Supplement. CLSI document M100-S21. 